\title{
Cultural Religiosity as the Determinant Factor of a Successful Healthy City in South Kalimantan, Indonesia
}

\author{
Herawati ${ }^{1}$, Shrimarti R. Devy ${ }^{2}$ \\ ${ }^{1}$ Doctoral Program of Public Health, Faculty of Public Health, Universitas Airlangga, Mulyorejo, Surabaya, \\ Indonesia, School of Nursing, Universitas Lambung Mangkurat; ${ }^{2}$ Department of Health Promotion \& Health \\ Behaviour, Faculty of Public Health, Universitas Airlangga, Mulyorejo, Surabaya, Indonesia
}

\begin{abstract}
The concept and processes of a healthy city was vary depends on the region. Each city should be allowed to develop and adapt to the uniqueness, culture and value of the respective society. This study aimed to explore the culture of community in Banjar, South Kalimantan, which related to realize healthy city. Qualitative research was conducted through community observation in the form of a documentation study, including an in-depth interview with several people and the respective community leaders. The data was analysed using the Miles and Huberman Model, including data reduction, data presentation and conclusion. There is the existence of a religious culture of the Banjar people of South Kalimantan. Religious cultures can be integrated into people's lives such as in the execution of healthy behaviour, which can be a determinant of a successful healthy city program.
\end{abstract}

Keywords: cultural religiosity, healthy city, Indonesia

\section{INTRODUCTION}

Health issue is significantly relevance to urban planning. Healthy urban planning could shape healthy social and environmental circumstances and vice versa, poor urban planning may contribute to the eruption of various diseases in the inhabitants within an urban area ${ }^{1}$. Urban issues do not only impact health and environment problems, but also be the key to achieve Sustainable Development Goals (SDGs) of creating favourable, safe and sustainable cities and residences (goal 11) ${ }^{2}$.

To overcome this health problem, a specific program is required. Public health programs, which maintain various relations between health services, residents and the urban area, are often not executed at a sufficient level. One of the programs initiated by the WHO was the "Healthy City Project" in 1986. This project was later spread, swiftly covering more than

\section{Corresponding Author:}

\section{Herawati}

Doctoral Program of Public Health, Faculty of Public Health, Universitas Airlangga; School of Nursing, Universitas Lambung Mangkurat Email: herawati-2017@fkm.unair.ac.id
7,500 cities around the world and more than 1,200 cities in Europe have come to the same perspective in order to revitalise the approach to health issues in urban life ${ }^{3,4}$ pleasant, and green built environment, but also one that creates and sustains health by addressing social, economic, and political conditions. It describes collaborations between city planning and public health creating a contemporary concept of urban governance?a democratically-informed process that embraces values like equity. Models, critiques, and global examples illustrate institutional change, community input, targeted assessment, and other means of addressing longstanding sources of urban health challenges. In these ambitious pages, healthy cities are rooted firmly in the worldwide movement toward balanced and sustainable urbanization, developed not to disguise or displace entrenched health and social problems, but to encourage and foster solutions. Included in the coverage: Towards healthy urban governance in the century of the city Healthy cities emerge: Toronto, Ottawa, Copenhagen The role of policy coalitions in understanding community participation in healthy cities projects Health impact assessment at the local level The logic of method for evaluating healthy cities Plus: extended reports on healthy cities and communities in North and Latin 
America, Africa, Europe, Asia, Oceania, and the Middle East Healthy Cities will interest and inspire community leaders, activists, politicians, and entrepreneurs working to improve health and well-being at the local level, as well as public health and urban development scholars and professionals. Part I: Foundations and Historical Backdrop -- Introduction: Aims and Objectives of this Book -- Paleo-Epidemiology, Nomadism and Sedentism: Health and the City -- Urbanisation and Public Health -- Health in Canada in the 1970s and 1980s: Hotbed of Innovation -- Healthy Cities Emerge: Toronto -- Ottawa -- Copenhagen -- Healthy Cities Grow: Development of International, National, Regional, Linguistic Networks -Eleven Qualities a City Should Strive to Provide (1986.

The concept of a healthy city is both an oldfashioned and new concept. "Old-fashioned" means that human beings have attempted to create healthier cities since the earliest periods of urban civilization. "New" is manifested as the primary medium of health promotion - new public health - in the search of health for all ${ }^{5}$. Healthy city approaches have long been known as the most popular approach in the promotion of health ${ }^{4}$.

A healthy city is an operational measure from a social model which aims to overcome negative health determinants ${ }^{6}$. Health determinants are an important or essential factor used to increase health performance ${ }^{7,8}$. The WHO European Healthy Cities Network has from its inception aimed at tackling inequalities in health. In carrying out an evaluation of Phase $\mathrm{V}$ of the project (2009-13. The WHO mentioned that a health determinant consists of the following: the social and economic environment and the physical and mental characteristics of the individual ${ }^{9}$.

The Human Development Index (HDI) data from the district of Banjar in 2015 was situated at rank 9 out of the 13 districts/cities existing in the province of South Kalimantan, and in 2016, the value of the HDI had relatively increased ${ }^{10}$. However, the rank slightly dropped to $10^{\text {th }}$. One of the primary causes was the health issue present, aside from education and the economy. In 2016, the achievement target of a sanitary and healthy lifestyle in the level of household was still stood in the percentage of $47.6 \%$ from the overall amount of 39.765 households observed ${ }^{10}$. Individual behaviour is shaped by culture ${ }^{11}$.

Further, every city has the possibility to develop respective parameters in accordance with the situational uniqueness, culture and values ${ }^{12}$. Nevertheless, the research in this field is exceptionally limited, primarily in the context of the local government ${ }^{~}$. Due to the concept of health, ill perceptions are deeply attached to the concept of culture, and so this pushes researchers to dive further into societal culture, particularly in relation to a healthy attitude in order to realise a healthy city in the District of Banjar, South Kalimantan Province. Through comprehending the particular societal culture of the city in question, it is further expected that precise interventions can be delivered to achieve an optimal level of health ${ }^{13,14}$.

Thus, this study aimed to explore the culture of community in Banjar, South Kalimantan, which related to realize healthy city.

\section{METHOD}

Observation over the behaviour of society and indepth interviews with the citizens and public figures of Banjar were conducted. The interviewed public figures consisted of chief of sub-divisions in municipal public health office of Banjar, director of a pesantren (Islamic Boarding School), chief-deputy of Healthy City Forum and chief of working cluster of Indrasari Urban Village. The interview was also conducted within wider society amounted to 15 individuals.

The questions prepared for this survey were openended. If the participants encountered difficulty when answering the questions or responded only briefly, then the researcher tried to deepen or follow up the information by requesting a further explanation about the participant's previous comment or requesting the participant to provide evidence from what they meant on the first occasion. The frequency and duration of interviews were in accordance with the initial commitment; around 60 to 90 minutes. However, it was limitless and manageable according to the situation and condition of the participants.

An unstructured passive participative observation was performed. The study did not use a default or systematically prepared instrument. A behavioural observation of the society and the condition of the physical environment were also conducted. Through observations, the researcher was equipped with a deeper knowledge in order to comprehend the data context across the entire social situation in order to be equipped with a holistic 
and thorough perspective. The data was analysed using the Miles and Huberman Model, including data reduction, data presentation and conclusion.

\section{RESULTS}

The study was located in Banjar, one of the regencies in South Kalimantan. The Banjar lays claim to a popular designation called "The Piazza of Mecca". The district has been visited by numerous scholars and the territory has been dominated by Muslims. However, there are a number of worshippers from various beliefs although on a lesser scale. In 2016, the citizens were made up of $99.20 \%$ Muslims, $0.27 \%$ followed Protestant Christianity, $0.25 \%$ followed Hinduism, and the rest followed Catholic Christianity and Buddhism/Animism with the percentage being $0.12 \%$ and $0.07 \%$ respectively and with other beliefs being $0.10 \%$.

In 1835, during the government of Sultan Adam Alwasiqubillah, for the first time a sharia law was implemented in the sultanate of Banjar. Nowadays, Banjar has 19 sub-districts with 29 villages or urban villages situated in the city of Martapura. The motto of Banjar contains three key words of baiman (have religious atmosphere), bauntung (blessed by the God), and batuah (have noble characters).

The results show that the society of Banjar has a cultural uniqueness with a depth focused on religious values. In several areas in Banjar district territory, there were a number of Islamic boarding school. The other unique factor of this district was the written Arabic texts in the naming of public offices. This is supported by the result of an interview with one of the public figures in the society who said that:

"Banjar society tends to choose religious education such as in pesantren (Islamic boarding school), which commences from elementary level. The schools become the favourite of Banjar society, as it includes the subject of Arabic".

Another similar statement came from another public figure, as follows:

"Banjar society views that formal school does not guarantee a wealthy life. It is different when it comes to learning religious subjects, hence worldly matters shall follow. This is a lead into a rewarding life. There are tons of people in Banjar who did not go to formal school but they were able to become rich or sufficient economically"

South Kalimantan is popularly known as the city of a thousand rivers. One of the rivers is Sungai Barito, which passes through several areas in Banjar. From the observations, the particular river has been frequently used by the society as a means of transportation as well as in the fulfilment of their daily needs such as bathing, laundry washing, and defecating. Numerous people have been misusing it for unwise and deteriorating activities, such as disposing their trash in the river. Based on the results of a series of interviews from a number of informants from the civil sector of society, they revealed that the attitude of using the river for a variety of needs or to dispose of trash has been habituated and committed to over generations and therefore it is difficult to be corrected, primarily for those living in the periphery of the river. These facts can be identified from the account made by an informant from the civil section of society as follows:

"How about it? It has been habituated for so long, therefore it is difficult to be eliminated."

Meanwhile, what has been conveyed by the public figure is not significantly different. The statement is as follows:

"Well... actually based on our perspective in our religion (Islam), it is crystal clear and comprehensive in detailing the ideas about health. In our culture, there is a saying that relates to 'cleaning up'. However, because society preserves the river, there are still many people using the river to defecate in."

Later on, from another public figure (religious), they revealed that among other things:

"There are have been so many students (santri) bathing in the river. Truly it is because such local culture has been difficult to change and eliminate."

In relation to the previous efforts made by public figures and the local government, this matter has been conveyed by the municipal public health office.

"Truly, it is because socialisation has not been delivered intensively, so it is normal if the participation of society is still lacking due to the minimum level of understanding. The program of a 'Healthy City' originally belonged to society, 
and the public health office as the authority should only act as a facilitator. The point is how it changes the behaviour of the society, whereas changing the attitude is not so simple."

There is a willingness and hope from the religious public figures on this matter that the figures are able to assist in transforming society's attitude to better behaviour as follows:

"Well, our hope is that we are going to be involved because for the time being, there are no invitations from the public health centres, the public health office and the other stakeholders to prompt discussion. If we are being involved, we will be forever grateful to be able to help. Hence, if our students are well-informed on health matters, they will extend this knowledge to others. That way, once they return home, they will be the role model in their villages and of course, be heard by their fellow villagers."

\section{DISCUSSION}

The study discovered that the culture and religious values has been developed and dominated the structure of Banjar society. However, the religious values have not yet impacted holistically on their lives, including on the matter of health.

The pendulum definition or healthy statement has moved away from the medical model and returned to the social model which is not only focuses on individual but also considers the result of social, economic and cultural factors related to society ${ }^{15,16}$. Many scholars had comprehended the prominence of culture to later on combine cultural content in the public health services ${ }^{17}$. According to Leininger, if the cultures of society do not fit with the health discourse, then the culture should be a subject for negotiation and need to be eliminated. However, if it is appropriate and able to support the health problems, then the particular culture should be preserved ${ }^{13}$.

Culture is a pattern of meaning. It is similar to the symbols that are historically distributed; a system of legacy that is consolidated, preserved, and developed by human-beings in the form of knowledge and attitude in their lives which is historically transmitted. One of the manifestations of culture can be contextualised in religion ${ }^{18,19}$.
Religion is seen of as a structure of various beliefs and the implementation of custom which is integrated into the cultural life of society. It is a working framework used to comprehend and create decisions. Religion can be defined as a system of rational belief through practices and/or as a set of beliefs, rituals and morals ${ }^{20,21}$. Religion can also be beneficial as a source of power to be abided by in the context of values and attitude. The majority of religions are equipped with a tradition involving certain beliefs and practices related to the afterlife and life attitude, either well or ill ${ }^{18,22}$.

Islam is a religion which highly encourages humanbeings to maintain cleanliness in life, to be healthy and to be environmentally-friendly. There are a number of verses in the Quran and Hadiths of the prophet, which contain various messages related to the encouragements. Health, with its respective paradigm, can be applied when disseminating information regarding the application of Islamic values, hence, there is no gap between the holiness of Islamic teaching with daily life attitude from the perspective of health ${ }^{23}$.

\section{CONCLUSION}

There is a major power possessed by society, which is the capacity of social capital through culture in form of religious values. This particular matter can support and act as a determinant to actualise a healthy city if the society is capable of realising the particular values involved in the transformation of a healthy lifestyle and the existence of a favourable partnership between society and public figures.

\section{Conflict of Interest: None.}

Ethical Clearance: The study passed ethical clearance from Ethical Committee of the Faculty of Publich Health, Universitas Airlangga, Surabaya, Indonesia.

Source of Funding: Self-funded.

\section{REFERENCES}

1. Palutturi S, Darmawansyah D, Nurhayani N. Partnership Pemerintah Pusat, Provinsi dan Kota Terhadap Implementasi Healthy Cities di Indonesia: Studi Kasus di Makasar. Universitas Hasanuddin;

2. Balaban O, Puppim de Oliveira JA. Sustainable buildings for healthier cities: assessing the co- 
benefits of green buildings in Japan. J Clean Prod [Internet]. 2017 Oct [cited 2018 Sep 20];163:S6878. Available from: https://linkinghub.elsevier. com/retrieve/pii/S0959652616001359

3. Leeuw E de, Simos J. Healthy cities : the theory, policy, and practice of value-based urban planning. 2015. 515 p.

4. Hu SC, Kuo H-W. The development and achievement of a healthy cities network in Taiwan: sharing leadership and partnership building. Glob Health Promot [Internet]. 2016 Mar 19 [cited 2018 Sep 20];23(1_suppl):8-17. Available from: http://journals.sagepub.com/ doi/10.1177/1757975916641566

5. Soedirham O. Kota Sehat sebagai Bentuk Sustainable Communities Best Practice. Kesmas Natl Public Heal J [Internet]. 2012 Sep 1 [cited 2018 Sep 20];7(2):51. Available from: http:// journal.fkm.ui.ac.id/kesmas/article/view/9

6. de Leeuw E. Evidence for Healthy Cities: reflections on practice, method and theory. Health Promot Int [Internet]. 2009 Nov 1 [cited 2018 Sep 20];24(Supplement 1):i19-36. Available from: http://www.ncbi.nlm.nih.gov/pubmed/19914985

7. Logie C. The case for the World Health Organization's Commission on the Social Determinants of Health to address sexual orientation. Am J Public Health [Internet]. 2012 Jul [cited 2018 Sep 20];102(7):1243-6. Available from: http://www.ncbi.nlm.nih.gov/ pubmed/22594723

8. Ritsatakis A, Ostergren P-O, Webster P. Tackling the social determinants of inequalities in health during Phase V of the Healthy Cities Project in Europe. Health Promot Int [Internet]. 2015 Jun 1 [cited 2018 Sep 20];30(suppl 1):i45-53. Available from: http://www.ncbi.nlm.nih.gov/ pubmed/26069317

9. World Health Organization. WHO $\mid$ The determinants of health [Internet]. WHO. World Health Organization; 2010 [cited 2018 Sep 20]. Available from: http:// www.who.int/hia/evidence/doh/en/

10. Dinas Kesehatan Kabupaten Banjar. Profil Kesehatan Kabupaten Banjar Tahun 2016. Martapura: Dinas Kesehatan Kabupaten Banjar; 2017.
11. Ellinas C, Allan N, Johansson A. Dynamics of organizational culture: Individual beliefs vs. social conformity. PLoS One [Internet]. 2017 [cited 2018 Sep 20];12(6):e0180193. Available from: http://www.ncbi.nlm.nih.gov/pubmed/28665960

12. World Health Organization. WHO Healthy Cities Project: Promoting Health in the Urban Context [Internet]. Geneva: World Health Organization; 2000 [cited 2018 Sep 20]. 1-47 p. Available from: http://www.euro.who.int/__data/assets/pdf_ file/0013/101650/E87743.pdf

13. McFarland M. Medeline Leininger: Culture care theory of diversity and universality. In: Tomey, A. M. \& Alligood MR, editor. Nursing theorists and their work. St. Louis, Missouri: Mosby, Inc.; 2006. p. 472-96.

14. Purnell LD. Transcultural health care : a culturally competent approach [Internet]. F.A. Davis; 2013 [cited 2018 Sep 20]. 505 p. Available from: https://www.fadavis.com/product/transculturalhealth-care-competent-purnell

15. World Health Organization. Constitution of the World Health Organization. Basic Documents, Forty-fifth edition, Supplement, October 2006 [Internet]. Geneva: World Health Organization; 2006 [cited 2018 Sep 20]. p. 1-20. Available from: http://www.who.int/governance/eb/who_ constitution_en.pdf

16. WHOQOL SRPB Group. A cross-cultural study of spirituality, religion, and personal beliefs as components of quality of life. Soc Sci Med [Internet]. 2006 Mar [cited 2018 Sep 20];62(6):1486-97. Available from: http://www. ncbi.nlm.nih.gov/pubmed/16168541

17. Sagar P. Transcultural Nursing Theory and Models: Application in Nursing Education, Practice, and Administration [Internet]. New York: Springer Publishing Company, LLC; 2012 [cited 2018 Sep 20]. Available from: http://ghttp.48653.nexcesscdn.net/ 80223CF/ springer-static/ media/ samplechapters/ 9780826107480/9780826107480_chapter.pdf

18. Rumun AJ. Influence of Religious Beliefs on Healthcare Practice. Int J Educ Res [Internet]. 2014 [cited 2018 Sep 20];2(4):37-48. Available from: www.ijern.com 
19. Inbadas H, Inbadas, Hamilton. History, Culture and Traditions: The Silent Spaces in the Study of Spirituality at the End of Life. Religions [Internet]. 2016 May 9 [cited 2018 Sep 20];7(5):53. Available from: http://www.mdpi.com/2077-1444/7/5/53

20. Molzahn AE, Sheilds L. Why is it so hard to talk about spirituality? Can Nurse [Internet]. 2008 Jan [cited 2018 Sep 20];104(1):25-9. Available from: http://www.ncbi.nlm.nih.gov/pubmed/18286982

21. Johnson GE, Wright FC, Foster K. The impact of rural outreach programs on medical students' future rural intentions and working locations: a systematic review. BMCMedEduc[Internet]. 2018
Dec 14 [cited 2018 Sep 6];18(1):196. Available from: https://bmcmededuc.biomedcentral.com/ articles/10.1186/s12909-018-1287-y

22. Haynes A, Hilbers J, Kivikko J, Ratnavyuha D. Spirituality and Religion in Health Care Practice A person-centred resource for staff at the Prince of Wales Hospital Multicultural Health Unit [Internet]. Sydney; 2007 [cited 2018 Sep 20]. Available from: https://www.rch.org.au/ uploadedFiles/Main/Content/cultural_services/ Spirituality_Staff_Resource.pdf

23. Taufik MT. Pendidikan Kesehatan Bernuansa Agama. Serang: Rineka Cipta; 2007. 